\title{
ACUTE PELLAGRA \\ IN A CHILD UNDER TREATMENT WITH ISONIAZID
}

BY

\author{
M. G. PHILPOTT and H. P. PLAYER \\ From the Victoria Hospital for Sick Children, Hull
}

(RECEIVED FOR PUBLICATION JULY 23, 1958)

Toxic manifestations during isoniazid therapy are encountered in less than $5 \%$ of cases treated, and we have been able to trace little mention of them in children in the literature. The drug is now widely used in the treatment of tuberculosis and is universally prescribed as an adjuvant to streptomycin in tuberculous meningitis. The following case report concerns a child who developed pellagra late in the treatment for tuberculous meningitis.

\section{Case Report}

Betty S., aged 8 years 11 months, was admitted to Victoria Hospital for Sick Children, Hull, in October, 1956, with a week's illness characterized by fever, headache and some vomiting. She had been seen first on the third day of symptoms. On admission she was fully conscious, but had spinal rigidity, early papilloedema, and weakness of the left internal rectus. A diagnosis of tuberculous meningitis was confirmed by examination of the cerebrospinal fluid and the tuberculin reaction (Heaf) was strongly positive. No primary complex was located, and no tuberculous contact was known. The girl, living in the country, may have had access to raw milk. A full course of treatment was commenced on the day of admission, consisting of streptomycin, $10 \mathrm{mg}$.//b. 12-hourly, intramuscularly; para-amino-salicylic acid, $250 \mathrm{mg}$./lb. daily, in four-hourly doses; and isoniazid, $5 \mathrm{mg}$./lb. daily in eight-hourly doses orally. Her weight was $59 \mathrm{lb}$. and for working out the doses, the figure of $60 \mathrm{lb}$. was used initially. She was also given $60 \mathrm{mg}$. of streptomycin intrathecally every day for six days a week. Progress was satisfactory but slow. The intrathecal injections were reduced to two a week after two months, and were not discontinued until January 21,1957 . The intramuscular streptomycin was discontinued on April 8 and the girl was discharged home on May 8. At that time she was extremely well and the C.S.F. had returned to normal. Para-amino-salicylic acid and isoniazid were continued, the doses having been adjusted for weight increase. At an out-patient attendance in May she was still very well.

The girl was seen at home on May 27 owing to the development of a rash on her face, hands and shins two days previously. Intellect was normal. By June 4, when she was next examined, there was weakness of all four limbs. The skin of the face, the backs of the hands, and the shins were glazed, dull red and pigmented, and the skin of the right hand had been easily broken by a football (Fig. 1). There were sordes around the mouth

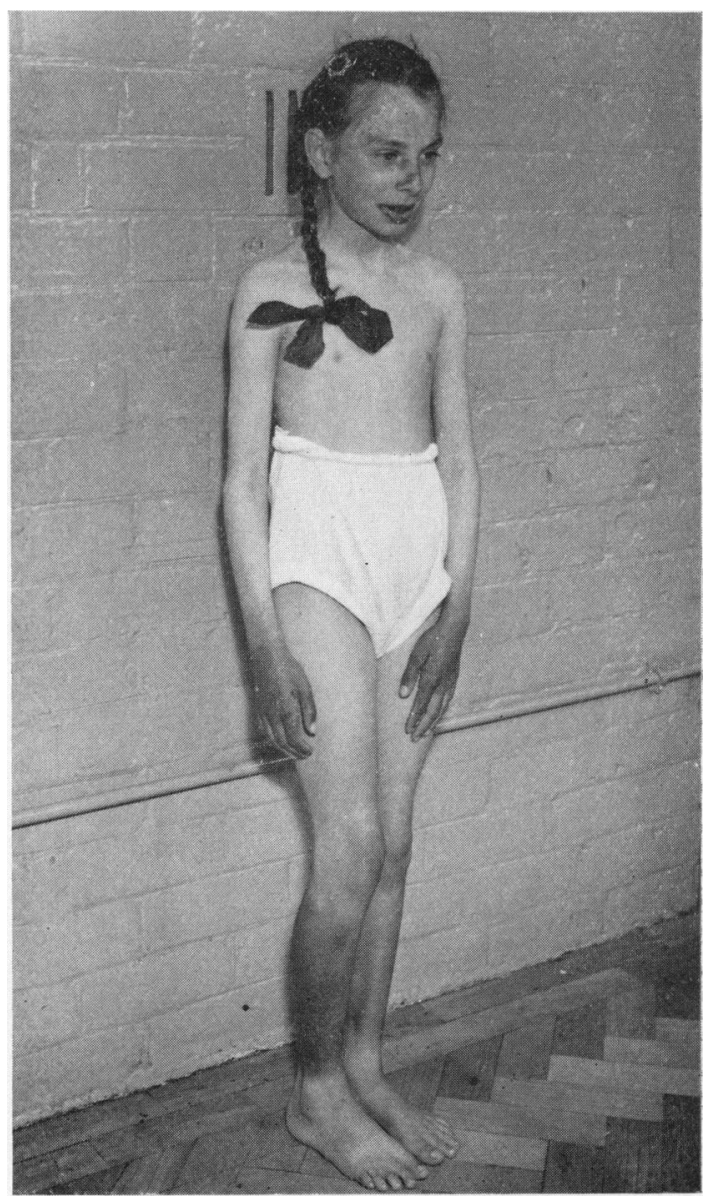

FiG. 1.-Betty S. 
and the tongue was glazed and sore. The reflexes were all diminished. Bowel function was normal. The picture suggested pellagra and the girl was readmitted to hospital. All treatment was discontinued and she was given 2 dr. eight-hourly of a vitamin B complex containing aneurine hydrochloride, $10 \mathrm{mg}$; nicotinamide, $40 \mathrm{mg}$; riboflavine, $10 \mathrm{mg}$; ; pyridoxine, $10 \mathrm{mg}$.; and $\mathrm{d} /$ calcium pantothenate, $10 \mathrm{mg}$. per fluid oz. The child improved rapidly, and all signs and symptoms had cleared by June 16, when she was discharged home again. The vitamin B complex was continued until July 23 and the para-amino-salicylic acid and isoniazid were never reintroduced. The girl has remained in the best of health ever since.

\section{Discussion}

It seemed unlikely that this picture of acute pellagra was due to para-amino-salicylic acid, but reports of similar toxic effects from isoniazid in adults had been made. Pegum (1952) described a patient with 'burning feet'. McConnell and Cheetham (1952) and Harrison and Feiwel (1956) reported cases of acute pellagra. Interference with nicotinic acid metabolism was indicated as the cause of the symptoms in these cases. Biehl and Vilter (1954) have shown that disorganization of pyridoxine metabolism occurs during isoniazid medication and Ungar, Parkin, Tomich and Muggleton (1954), experimenting with mice, came to similar conclusions. It is of interest, however, that the case of Harrison and Feiwel (1956) was receiving added pyridoxine during isoniazid therapy and yet developed symptoms. Wood (1955) reported pellagra in ill-nourished tuberculous patients treated with isoniazid which was difficult to control with added vitamin B complex. A review of the neurotoxic effects of isoniazid was made in a recent leading article (British Medical Journal, 1958).
While in hospital our patient was taking a full diet and vitamin supplements providing approximately aneurine $1 \mathrm{mg}$., riboflavine $1 \mathrm{mg}$., pantothenic acid $0.5 \mathrm{mg}$. and nicotinic acid $6 \mathrm{mg}$. daily. After discharge no vitamin preparations were given and the diet may not have been as well regulated. There had been a week of very sunny weather during the time the symptoms developed, but the child denied going out of doors very much.

From the clinical point of view some interference with nicotinic acid metabolism seems to be probable in this case although pyridoxine, and possibly riboflavine, were also affected. Certainly there was a most dramatic response to vitamin B complex therapy, and it would behove those treating children with isoniazid to ensure a satisfactory dietary intake and prescribe vitamin B supplements.

\section{Summary}

A case of acute pellagra is reported occurring in a girl aged 9 years 8 months after commencing treatment for tuberculous meningitis. The condition cleared in less than two weeks on discontinuing isoniazid therapy and introducing vitamin $\mathbf{B}$ complex. To avoid toxic manifestations from isoniazid it seems reasonable to administer vitamin B supplements during treatment with this drug.

Our thanks are due to Dr. R. J. Pugh who commented on this paper.

\section{REFERENCES}

Biehl, J. P. and Vilter, R. W. (1954). J. Amer. med. Ass., 156, 1549. British Medical Journal (1958). Leading article. 1, 880.

Harrison, R. J. and Feiwel, M. (1956). Brit. med. J., 2, 852.

McConnell, R. B. and Cheetham, H. D. (1952). Lancet, 2, 959.

McConnell, R. B. and Cheetham, H
Pegum. J. S. (1952). Ibid., 2, 536.

Ungar, J., Parkin, K. R., Tomich, E. G. and Muggleton, P. W. (1954). Ibid., 2, 220.

Wood, M. M. (1955). Brit. J. Tuberc., 49, 20. 